\title{
Volatiles Constituents from Leaves of Morinda morindoüdes (Rubiaceae): A Medicinal Plant from the Ivory Coast
}

\author{
F.P. Bi Kouame ${ }^{1}$, G. Bedi*, ${ }^{*}$, A.M. Koffi ${ }^{1}$, J.C. Chalchat ${ }^{2}$ and T. Y. N'Guessan ${ }^{1}$ \\ ${ }^{1}$ Laboratoire de Chimie Organique Biologique, UFR SSMT, 08 BP 582 Abidjan 08, Université de Cocody, Côte \\ d'Ivoire; ${ }^{2}$ Laboratoire de chimie des Hétérocycles, des Glucides Chimie et des huiles essentielles, Les Cezeaux, 63177, \\ Aubière, France
}

\begin{abstract}
The essential oil of Morinda morindoïdes, a famous medicinal herb from the Mid-West Ivory Coast, was isolated in low percentage $0,2 \% \mathrm{w} / \mathrm{w}$ and studied by GC and GC/MS. The analysis showed the presence of 50 compounds (91.8\%). These consisted of 3 diterpenes (29.6\%), 30 sesquiterpenes (35.4\%) 10 monoterpenes (14.7\%) and 7 aromatics compounds (12.1\%). The main components were trans-phytol (28.4\%), 6, 10, 14-triméthylpentadecan-2-one $(9.6 \%)$ and linalol $(8.4 \%)$ as secondary products.
\end{abstract}

Keywords: Morinda morindoïdes, hydrodistillation, diterpenes, trans-phytol, 6,10,14-triméthylpentadecan-2-one, linalol.

\section{INTRODUCTION}

Morinda morindoïdes (Baker) Milne-redheat (Rubiaceae) is a small tree which grows in forest locations. In the Ivory Coast, people have used the aqueous extract of the leaves of this plant in the treatment of paludism, measles and chickenpox because of its fever-attenuating properties. Several studies based on the biological activity of the aqueous or organic extract of this plant were described particularly with regard to antimalaria and antibacterial activities. The ethanol and methylene chloride extracts from Morinda morindoïdes have been used for the treatment of malaria in the Congo and have been shown to inhibit Plasmodium falciparum growth in vitro [1]. Ethanolic, dichloromethane and lyophilized aqueous extracts of Morinda morindö̈des have been shown to be effective in vivo against Plasmodium berghei ANKA in mice [2]; a petroleum ether extract showed significant in vitro inhibition of antiplasmodial activity when compared to an ethanolic extract [3]. Five iridoids isolated from an $80 \%$ methanolic extract from an aqueous decoction of leaves of Morinda morindoides exhibited promising anti-amoebic activity [4]. Recently, an acetic acid extract (ACE) of Morinda morindoïdes (Baker) Milne Redheat leaves showed in vitro antibacterial activity on the growth of Escherichia coli, which is responsible for diarrhea in children [5].

The goal of this study is to identify the structures of volatile components of the essential oil of the leaves of Morinda morindoïdes from Ivory Coast, which might be responsible for the reported biological activity of this plant.

\section{EXPERIMENTAL}

\section{Plant Materials}

Fully matured leaves of Morinda morindö̈des were freshly collected in May, 2008 at 8 am local time from trees

\footnotetext{
*Address correspondence to this author at the Laboratoire de Chimie Organique Biologique, UFR SSMT, 08 BP 582 Abidjan 08, Université de Cocody, Côte d'Ivoire, France; Tel: 00225059989 84;

E-mail: Bedisag@yahoo.fr
}

growing at a location in the village of Bobia in the Ivory Coast. Voucher specimens were identified by Professor Ake Assi from the Floristic Center of Cocody University of the Ivory Coast. $500 \mathrm{~g}$ of leaves were conditioned to be distilled in water.

\section{Isolation of Essential Oil}

The fresh leaves of the plant $(500 \mathrm{~g})$ were distilled in 200 $\mathrm{mL}$ of water for $2 \mathrm{~h}$ in a Clevenger-type apparatus. The collected essential oil was dried over anhydrous sodium sulphate and preserved in a sealed sample tube and stored at $0^{\circ} \mathrm{C}$ until GC and GC-MS analyses.

\section{Chemical Analyses}

The essential oil was investigated first by gas chromatography (GC) and then by GC coupled with mass spectral detection (GC-MS). Concerning GC analysis, the gas phase chromatography was carried out using a Delsi DI 200 instrument equipped with a flame ionization detector and a DB5 column ( $25 \mathrm{~m}$ x $0.25 \mathrm{~mm}$, df: 0.25 micro m) with a split flow rate of $60 \mathrm{~mL} / \mathrm{min}$. Nitrogen was used as carrier gas; temperature programming was $5 \mathrm{~min}$ at $50^{\circ} \mathrm{C}$ and $30^{\circ} \mathrm{C} / \mathrm{min}$ up to $220^{\circ} \mathrm{C}$, injector temperature was $220^{\circ} \mathrm{C}$ and detector temperature was $250^{\circ} \mathrm{C}$. For GC-MS, the essential oil was analyzed using a Hewlett-Packard gas Chromatograph Model 6890 coupled to a Hewlett-Packard MS Model 6890 equipped with an HP5 column(30m x $0.25 \mathrm{~mm}$ df: 0.25 micro m) programmed from $50^{\circ} \mathrm{C}(5 \mathrm{~min})$ to $300^{\circ} \mathrm{C}$ at $50^{\circ} \mathrm{C} / \mathrm{min}$ and $5 \mathrm{~min}$ hold. The carrier gas was $\mathrm{He}(1.0 \mathrm{~mL} / \mathrm{min})$; injection was set in the split mode $(1 / 10)$. Injector and detector temperatures were $250^{\circ} \mathrm{C}$ and $320^{\circ} \mathrm{C}$, respectively. Ionization was by electron impact at $70 \mathrm{eV}$, the electron multiplier was set at $2200 \mathrm{~V}$, and ion source temperature was $230^{\circ} \mathrm{C}$. Mass spectral data were acquired in the scan mode in the $\mathrm{m} / \mathrm{z}$ range of 33-450. Identification of compounds was carried out by calculating Retention Indices (RI) or Koväts Indices (KI) and comparing mass spectra with those in data banks, i.e. Adams [6] or Mc Lafferty and Stauffer [7]. 
Table 1. Chemical Composition of Essential oil of Leaves of Morinda morindoüde

\begin{tabular}{|c|c|c|c|c|}
\hline \multirow{2}{*}{$\mathbf{N}^{\circ}$} & \multirow{2}{*}{$\mathbf{K I}$} & \multirow{2}{*}{$\mathbf{R I}$} & Compound & \multirow{2}{*}{ Content $\%, w / w$} \\
\hline & & & Monoterpenes & \\
\hline 1 & 1060 & 1060 & gamma terpinene & 0.2 \\
\hline 2 & 1072 & 1068 & n-octanol & 0.1 \\
\hline 3 & 1101 & 1096 & linalol & 8.4 \\
\hline 4 & 1104 & - & hotrienol & 0.1 \\
\hline 5 & 1193 & 1195 & alpha terpineol & 1.4 \\
\hline 6 & 1197 & 1190 & methyle salicylate & 1.2 \\
\hline 7 & 1221 & - & beta cyclocitral & 0.3 \\
\hline 8 & 1225 & 1230 & nerol & 0.7 \\
\hline 9 & 1251 & 1255 & geraniol & 1.5 \\
\hline \multirow[t]{3}{*}{10} & 1283 & - & vitispirane & 0.8 \\
\hline & & & Total monoterpenes & 14.7 \\
\hline & & & Sesquiterpenes & \\
\hline 11 & 1322 & 1330 & hex-3-enyle tiglate & 0.2 \\
\hline 12 & 1337 & 1340 & delta elemene & 0.4 \\
\hline 13 & 1380 & 1380 & (E)-beta-damascenone & 0.9 \\
\hline 14 & 1391 & 1389 & béta elemene & 0.6 \\
\hline 15 & 1424 & 1418 & béta caryophyllene & 3.1 \\
\hline 16 & 1429 & 1430 & (E)-alpha ionone & 0.1 \\
\hline 17 & 1447 & 1453 & geranyl acetone & 0.6 \\
\hline 18 & 1460 & 1454 & alpha humulene & 0.7 \\
\hline 19 & 1464 & 1463 & 6-demethoxy ageratochromene & 1.2 \\
\hline 20 & 1480 & 1485 & D -germacrene & 1.3 \\
\hline 21 & 1485 & 1489 & (E)-beta ionone & 0.4 \\
\hline 22 & 1493 & 1498 & alpha selinene & 0.8 \\
\hline 23 & 1499 & 1498 & tiglate de benzyle & 0.9 \\
\hline 24 & 1503 & 1506 & $(\mathrm{E}, \mathrm{E})$-alpha farnesene & 0.8 \\
\hline 25 & 1516 & 1514 & gamma cadinene & 0.3 \\
\hline 26 & 1520 & 1523 & delta cadinene & 0.3 \\
\hline 27 & 1529 & - & zingigerone & 0.2 \\
\hline 28 & 1551 & 1549 & elemol & 0.5 \\
\hline 29 & 1561 & 1564 & nerolidol & 0.3 \\
\hline 30 & 1613 & 1613 & tetradecanal & 0.5 \\
\hline 31 & 1628 & 1624 & 10-epi-gamma eudesmol & 1.3 \\
\hline 32 & 1655 & 1654 & alpha cadinol & 0.2 \\
\hline 33 & 1660 & 1664 & 7-epi-gamma eudesmol & 0.4 \\
\hline 34 & 1666 & 1669 & 'hex-3-enyle salicylate & 0.1 \\
\hline
\end{tabular}


(Table 1). Contd.....

\begin{tabular}{|c|c|c|c|c|}
\hline \multirow{2}{*}{$\mathbf{N}^{\circ}$} & \multirow{2}{*}{ KI } & \multirow{2}{*}{ RI } & Compound & \multirow{2}{*}{ Content $\%$, w/w } \\
\hline & & & Monoterpenes & \\
\hline 35 & 1702 & 1700 & eudesm-7(11)-en-4-ol & 0.4 \\
\hline 36 & 1715 & - & pentadecanal & 4.8 \\
\hline 37 & 1836 & 1837 & 6,10,14-trimethyl pentadecan-2-one & 9.6 \\
\hline 38 & 1872 & - & octadecan-9-yne & 1.3 \\
\hline 39 & 1878 & - & methyle linolenate & 2.9 \\
\hline \multirow[t]{3}{*}{40} & 1886 & - & farnesyle acetone & 0.3 \\
\hline & & & Total sesquiterpenes & 35.4 \\
\hline & & & Aromatic compounds & \\
\hline 41 & 1026 & 1025 & para cymene & 0.2 \\
\hline 42 & 1291 & 1290 & thymol & 7 \\
\hline 43 & 1573 & 1578 & $\mathrm{Z}$-hex-3-enyle benzoate & 1 \\
\hline 44 & 1581 & 1580 & hexyle benzoate & 0.5 \\
\hline 45 & 1587 & 1588 & E- 'hex-3-enyle benzoate & 0.8 \\
\hline 46 & 1770 & 1760 & benzyle benzoate & 0.9 \\
\hline \multirow[t]{3}{*}{47} & 1860 & 1866 & benzyle salicylate & 1.7 \\
\hline & & & Total aromatics compounds & 12.1 \\
\hline & & & Diterpenes & \\
\hline 48 & 1918 & 1944 & isophytol & 0.1 \\
\hline 49 & 1945 & 1987 & acide hexadecanoïque & 1.1 \\
\hline 50 & 2111 & - & Phytol trans & 28.4 \\
\hline & & & Total diterpenes & $2 ., 6$ \\
\hline & TOTAL & TOTAL & & 91.8 \\
\hline
\end{tabular}

\section{RESULTS AND DISCUSSION}

Morinda morindoïdes is an odorless plant, but the hydrodistillation of the fresh leaves of this plant gave essential oil in low yield (i.e. less than $0.2 \%$ ). The chemical constituents identified by GC and GC-SM are listed in Table 1.

Fifty compounds were identified representing $91.8 \%$ of volatiles. These volatiles were composed of 10 monoterpenes, 36 sesquiterpenes, 7 aromatic compounds and 3 diterpenes, amounting to $14.7 \%, 35.4 \%$, and $29.6 \% \mathrm{w} / \mathrm{w}$, respectively. The essential oil was dominated by the presence of the diterpene phytol (28.37\%), followed by 6,10,14-trimethyl pentadecan-2-one $(9.65 \%)$ and thymol $(7.02 \%)$. We observed initially that the yield of volatiles was comparable with that of Chromolaena odorata, a famous aromatic antipaludic and antiinflammatory plant used in the Ivory Coast [8]. Secondly, the diterpene phytol was one of constituents of chlorophyll, and was present in the extract of several previously described plants [9] [10]. Yoshihiro et al. showed that phytol had antibacterial activity, inhibiting the growth of Staphylococcus aureus [11]. Our study suggests that Morinda morindoïdes may be a potential source of trans- phytol for antiplasmodial (malaria), antibacterial (Escherichia coli) (diarrhea) and Entamoeba histolytica (amoebic pains) use in medicine.

\section{ACKNOWLEDGEMENT}

We thank Professor Ake Assi, for the identification of plant leaves and Mr. Gbazike Kagouehi Joachim, a resident of Bobia village, for the collection of plant material.

\section{REFERENCES}

[1] Tona, L.; Naimbi, NP.; Tsakala, M.; Mesia, K.; Cimanga, K.; Apers, S.; De Bruyne, T.; Pieters, L.; Totté, J.; Vlietinck, AJ. Antimalaria activity of 20 crude extracts from nine African medicinal plants used in Kinshasa, Congo. J. Ethnopharmacol., 1999, 68(13), 193-203.

[2] Tona, L.; Mesia, K.; Naimbi, NP.; Chrimwami, B.; Okond'ahoka, Cimanga, K.; De Bruyne, T.; Apers, S.; Hermans, N.; Totté, J.; Pieters, L. Vlietinck, A.J. In-vivo antimalaria activity of cassia occidentalis. Morinda morindoïdes and Phyllanthus A J. Ann. Trop. Med. Parasitol., 2001, 95(1), 47-57.

[3] Tona, L.; Cimanga, RK.; Mesia, K.; Musuamba, CT.; De Bruyne, T.; Apers, TS.; Hermans, N.; Van Miert, S.; Pieters, L.; Totté, J.; Vlietinck, AJ. In vitro antiplasmodial activity of extracts and fractions from seven medicinal plants used in the democratic Republic of Congo. J. Ethnopharmacol., 2004, 93(1), 27-32. 
[4] Cimanga, K.; Kambu, K.; Tona, L.; Hermans, N.; Apers, S.; Totté, J.; Pieters, L.; Vlietinck, AJ. Antiamoebic activity of iridoids from Morinda morindoides leaves. Planta Med., 2006, 72(8), 751-3.

[5] J-Moroh, L.A.; Bahi, C.; Dje, K.; Loukou, YG.; Guede Guina, F. Study of the antibacterial activity of Morinda morindoïdes( baker) milne-redheat(rubiaceae) acétique extract(ACE) on in-vitro growth of Escherichia coli strains. Bull. Soc. R. Sci. Liege, 2008, 77, 4461 .

[6] Adams, R.P. Identification of Essential OH Components by gas Chromatography / Mass Spectroscopy, Allured Publishing Corporation, Carol Stream, IL, 1995.

[7] Mc Lafferty, F.W.; Stauffer, D.B. The Willey NBS Registry of Mass Spectral Data, J. Wiley and Son, NY, 1989.

[8] Bedi, G.; Tonzibo, Z.F.; Chopard, C.; Mahy, J.P.; N'Guessan, T.Y. Etude des effets anti douleurs des huiles essentielles de Chromo- laena odorata et de Mikania cordata, par action sur la lipoxygénase L-1 de soja. Phys. Chem. News, 2004, 15, 124-127.

[9] Hayri, D.; Murat, K.; Altun, L.; Demirci, B.; Husnu Can Base, K. The essential oil of Stachys laetivirens Kotschy and Boiss. Flavour fragr J., 2004, 20(1), 48-50.

[10] Li, W.; Shuguang, J.; Peng, N.; Yang, Z. Chemical composition of the essential oil of Elephantopus scaber from southern China. Z Naturforsch, 2004, 59C, 327-329.

[11] Yoshihiro, I.; Toshiko, H.; Akiko, S.; Kazuma, H.; Hajime, H.; Shigeki, K. Biphasic effects of geranylgeraniol, terpenone and phytol on the growth of Staphylococcus aureus. Antimicrob. Agents Chemother., 2005, 49(5), 1770-1774.

(C) Bi Kouame et al.; Licensee Bentham Open.

This is an open access article licensed under the terms of the Creative Commons Attribution Non-Commercial License (http://creativecommons.org/licenses/by-nc/3.0/) which permits unrestricted, non-commercial use, distribution and reproduction in any medium, provided the work is properly cited. 